\title{
A remarkably well-preserved terrestrial isopod (Peracarida: Isopoda: Armadillidiidae) from the upper Oligocene of Hungary, with remarks on the oniscidean taphonomy
}

\author{
Matúš Hyžný and Arpád Dávid
}

\begin{abstract}
Isopods rank among the more successful and diverse peracaridan crustaceans, the clade of oniscidean isopods (pill-bugs and wood-lice) being one of the few pancrustacean groups to have successfully invaded terrestrial habitats. Yet, the majority of fossil occurrences of oniscidean isopods stem from amber deposits and only under very special circumstances are they preserved in marine settings; such an occurrence is recorded herein. A single, specifically indeterminate, specimen of Armadillidium from upper Oligocene strata at Eger (Hungary) is interpreted as a drowned individual that found itself trapped on a piece of driftwood or was caught by waves while walking on the seashore. The animal was preserved virtually intact and close to a natural posture. A near-perfect preservation of the isopod's cuticular surface indicates their potential to be preserved in marine siliciclastic settings under specific conditions.
\end{abstract}

Matúš Hyžný. Comenius University, Faculty of Natural Sciences, Department of Geology and Palaeontology, Ilkovičova 6, 84215 Bratislava, Slovakia; e-mail: hyzny.matus@gmail.com and Department of Geology and Palaeontology, Natural History Museum, Vienna, Burgring 7, 1010 Vienna, Austria Arpád Dávid. Debrecen University, Department of Mineralogy and Geology, Egyetemtér 1, 4032 Debrecen, Hungary

Keywords: Armadillidium; central Europe; cuticle preservation; Egerian; fossil

Submission: 23 November 2015 Acceptance: 23 February 2017

\section{INTRODUCTION}

Isopods are among the more successful and diverse peracaridan crustaceans to inhabit marine, freshwater and terrestrial habitats alike (Kussakin, 1979; Kensley and Schotte, 1989; Wägele, 1989; Warburg, 1993; Brusca et al., 2007; Wilson, 2008; Poore and Bruce, 2012; Sfenthourakis and Taiti,
2015). In fact, together with several representatives of amphipods and brachyuran decapods, oniscidean isopods are the only pancrustaceans (except for hexapods) to have adapted to terrestrial conditions (e.g., Hornung, 2011; Dunlop et al., 2013). Oniscideans probably originated during the Carboniferous (Broly et al., 2013), although the

Hyžný, Matúš and Dávid, Arpád. 2017. A remarkably well-preserved terrestrial isopod (Peracarida: Isopoda: Armadillidiidae) from the upper Oligocene of Hungary, with remarks on the oniscidean taphonomy. Palaeontologia Electronica 20.1.5A: 1-11 palaeo-electronica.org/content/2017/1757-oniscidean-isopod-from-hungary 


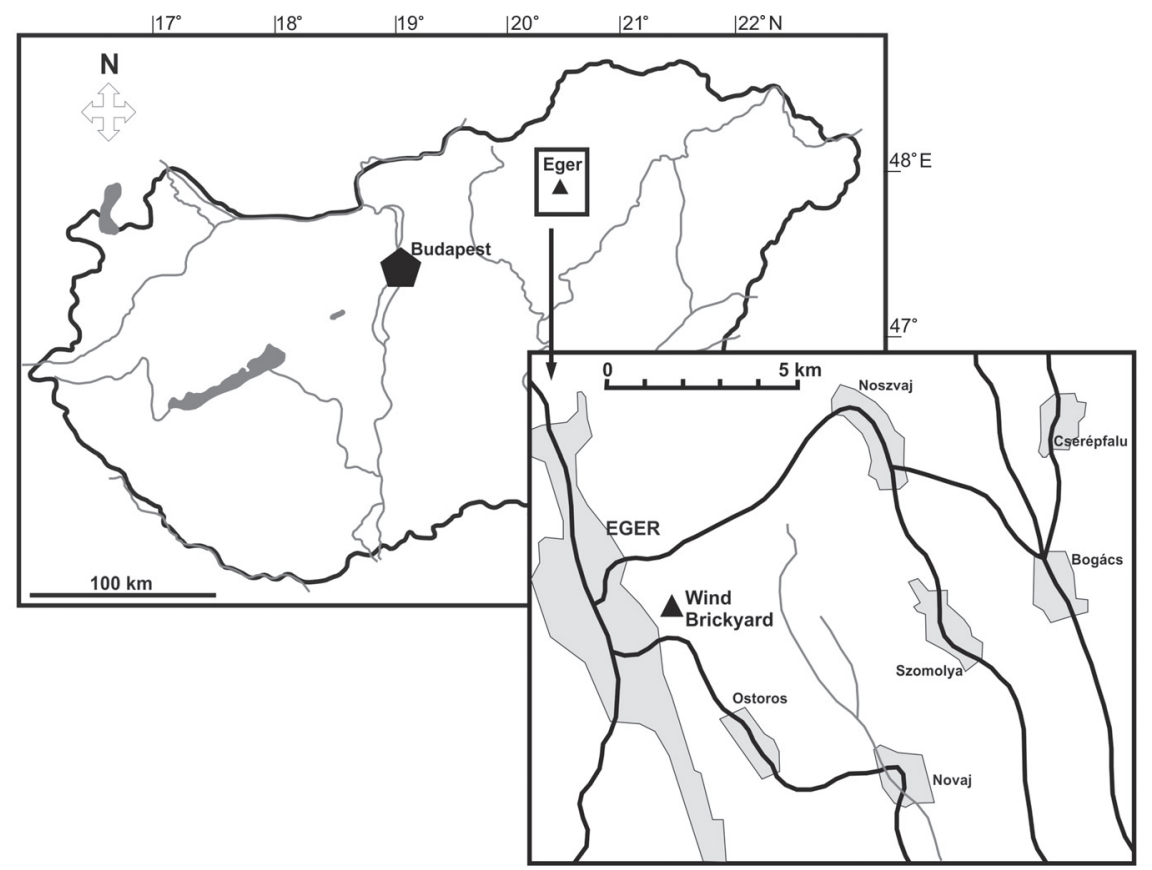

FIGURE 1. Position of the locality studied within Hungary.

oldest verified occurrence of an oniscidean fossil is from the Early Cretaceous (Broly et al., 2015).

The fossil record of isopods is insufficiently known, mainly because of the delicate nature of their exoskeleton and hence a low fossilisation potential. A direct consequence of this is that there are only a few occurrences in which the morphology of mouthparts or appendages, which are important for isopod systematics and taxonomy, are preserved (e.g., Guinot et al., 2005; Vega et al., 2005; Feldmann, 2009; Wilson et al., 2011; Nagler et al., 2016), including specimens preserved in amber (e.g., Spahr, 1993; Dunlop, 2010; Perkovsky et al., 2010). In view of the fact that oniscidean isopods live in terrestrial habitats, their fossils are scarce and are dominated by amber inclusions (Broly et al., 2013, 2015). Many isopod fossils, except those preserved in amber, are flattened and sometimes distorted due to taphonomical processes. In this respect, the armadillidiid isopod specimen from the Oligocene of Hungary reported herein is remarkable in its three-dimensional preservation.

Additionally, the specimen described herein represents the first fossil isopod from Hungary. From neighbouring countries, Mesozoic isopods have been recorded from Austria (Bachmayer, 1949, 1955; see also the review of Jurassic isopods by Etter, 2014) and Cenozoic species from Austria (von Ammon, 1882; Bachmayer, 1947; Tauber, 1950), the Czech Republic (Novák, 1872), Slo- vakia (Hyžný et al., 2013), Romania (Racovitza and Sevastos, 1910) and Ukraine (Perkovsky et al., 2010). However, nearly all these occurrences involve marine taxa, whereas only the Ukrainian occurrence is based on oniscideans preserved in amber (Perkovsky et al., 2010). Thus, the Hungarian specimen of a terrestrial isopod is a worthwhile addition to the isopod fossil record.

\section{GEOLOGICAL SETTING}

The described specimen originates from the Wind Brickyard, situated in the southeastern part of Eger, Hungary (GPS co-ordinates: 47 $53^{\prime} 47.55^{\prime \prime} \mathrm{N}$, $20^{\circ} 23^{\prime} 52.20^{\prime \prime} \mathrm{E}$; see Figure 1). This outcrop represents the stratotype of the Egerian Regional Stage of the Central Paratethys (Báldi and Seneš, 1975; for a correlation with the Mediterranean scale, see Piller et al., 2007). The sequence exposed belongs to nanoplankton zone NP 25 and the Paragloborotalia opima opima Biozone, corresponding to the Chattian (late Oligocene).

The Wind Brickyard section (Figure 2) exposes the lower part of the Eger Formation (Báldi and Seneš, 1975). Several marine facies (shallow bathyal, sublittoral, littoral and lagoonal) can be observed here, with diverse flora and fauna (e.g., Báldi, 1973; Kvaček and Hably, 1991; Dávid, 1993, 1999; Fodor, 2001; and references therein). Strata assigned to the Eger Formation rest conformably on the lower Oligocene Kiscell Clay For- 


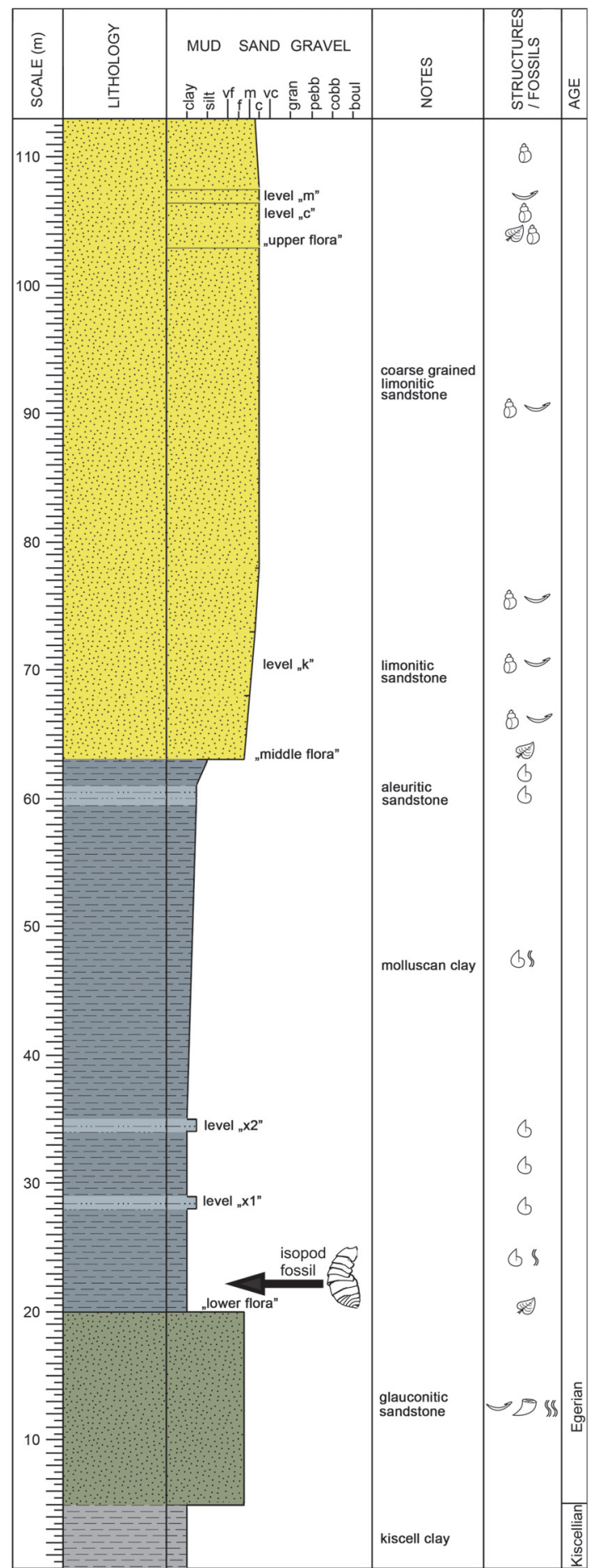

Legend:

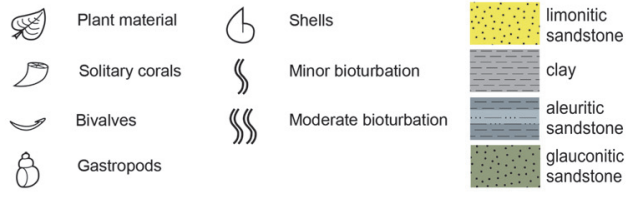

FIGURE 2. Section exposed at the Wind Brickyard in Eger, Hungary. See text for comments. mation (Báldi, 1983). Higher in the section, glauconitic tuffaceous sandstones are exposed, and above follows the so-called molluscan clay (thickness $35-40 \mathrm{~m}$ ), which contains a rich and diverse microfauna with foraminifera, small molluscs and teleost otoliths. Higher up, the $5.0-5.5 \mathrm{~m}$ thick sequence of sandy clay (called "middle flora") is exposed, followed by approximately $2 \mathrm{~m}$ of limonitic sandstones containing a varied, excellently preserved molluscan fauna. This level is referred to as the "k" layer (from "kövületes" for fossiliferous, in Hungarian). The succession continues with brackish, shallow-marine sands, the so-called "m" layer (from "mytilitic"). Finally, there is a 4-5 m thick level of limonitic sand on the top of the succession.

The isopod specimen was found in the molluscan clay, which was deposited in a deep sublittoral-shallow bathyal environment (Báldi, 1973, 1998). Gastropod, bivalve and dentaliid taxa belong to the Hinia-Cadulus community. The upper levels formed in shallow sublittoral (Pitar polytropa community) and littoral (TympanotonusPirenella and Mytilus aquitanicus communities) settings. The occurrence of pieces of driftwood in the molluscan clay, bioeroded by teredinid bivalves (Dávid, 2004), illustrates that different trunks could be transported by currents to great distances from the coast prior to settlement and final burial.

\section{SYSTEMATIC PALAEONTOLOGY}

Order ISOPODA Latreille, 1817 Suborder ONISCIDEA Latreille, 1802 Section CRINOCHETA Legrand, 1946 Family ARMADILLIDIIDAE Brandt, 1833

Remarks. Apparently, the Hungarian specimen was able to roll up into a ball, thus, it belongs to conglobating isopods. The general habitus of the specimen in question may fit to several oniscidean families, including Armadillidae, Armadillidiidae, or Eubelidae. One of the autapomorphies of the Eubelidae is sulcus arcuatus, a longitudinal grove on the first coxal plate (Taiti et al., 1991; Schmidt, 2003). The studied specimen does not possess this character, and hence its potential attribution to Eubelidae is disputed. The uropods of armadillidiids differ from the uropods of other conglobating Oniscidea: their exopodite is plate-like, truncate posteriorly. The exopodite fills out the gap between the pleotelson and the pleon-epimera 5 , and their truncate apical margin is part of the body outline (Schmidt, 2003). Unfortunately, the Hungarian specimen does not retain uropods. The pleotelson, however, is partly preserved and its outline is undoubtedly triangular, as it is typical for armadilli- 
HYŽNÝ \& DÁVID: ONISCIDEAN ISOPOD FROM HUNGARY

TABLE 1. Fossil occurrences of the family Armadillidiidae.

\begin{tabular}{lcccc}
\hline \multicolumn{1}{c}{ Species } & Age & Country & Setting & Reference \\
\hline Armadillidium vulgare & Pleistocene & France & clastics & Dalens and Bouthier (1985) \\
Eoarmadillidium granulatum & Pleistocene & France & clastics & Dollfus (1904) \\
gen. et sp. indet & early Miocene & Mexico & amber & Serrano et al. (2007) \\
Armadillidium pulchellum & late Oligocene & Germany & amber & Spahr (1993) \\
Armadillidium sp. & late Oligocene & Hungary & clastics & herein \\
gen. et sp. indet & Eocene & Northern Europe & amber & Weitschat and Wichard (2010) \\
& & & & \\
Disputed by Schmidt (2008) & & & & Heer (1865) \\
Armadillidium molassicum & middle Miocene & Germany & clastics & Srivastava et al. (2006) \\
Armadillidium payangadensis & ?Miocene & India & amber & .
\end{tabular}

diids (Schmidt, 2003), rather than quadrangular, which is typical for armadiliids (Schmidt, 2003). As a conclusion, the Hungarian specimen is assigned to the family Armadillidiidae. Up to now, only a handful of veritable occurrences of this family are known from the fossil record (Table 1).

Genus ARMADILLIDIUM Brandt, 1833

Type species. Armadillo vulgaris Latreille, 1804, by original designation.

Diagnosis. See Sars (1899, p. 188) and Richardson (1905, p. 665); see also Schmalfuss (2013, p. 13).

Remarks. Armadillidiids constitute a well-founded monophyletic group (Schmidt, 2008) that comprises about 300 species. The most speciose genus is Armadillidium Brandt, 1833, with nearly 200 described forms (Schmalfuss, 2003), including A. vulgare (Latreille, 1804), the "most extensively investigated species of terrestrial isopods," as noted by Schmalfuss (2003, p. 2). According to Schmalfuss (2013), the genus is defined by: 1) ability to roll up into a closed ball, which may have a lemon-like shape; 2 ) lungs with multiple spiracles in $1^{\text {st }}$ and $2^{\text {nd }}$ pleopod-exopodite; 3) uropod-exopodite flattened and truncated, filling the space between epimeron of pleonite 5 and telson; 4) frontal part of head with a triangular shield (which seems to be a modified supra-antennal line) reaching the level of the upper head surface or surpassing this level; 5) lateral parts of inter-ocular line present. Unfortunately, the Hungarian specimen does not possess a head, which precludes a confident generic assignment. However, we argue that based on various clues discussed below it is reasonable to assign the specimen to Armadillidium.

The pereonite-epimeron I does not have a notch (schisma), which is characteristic for many genera, i.e., Alloschizidium Verhoeff, 1919; Ballo- dillium Vandel, 1961; Eluma Budde-Lund, 1885; Paraschizidium Verhoeff, 1918; and Schizidium Verhoeff, 1901. Thus, the assignment of the Hungarian specimen to these genera can be excluded. Also, based on the smooth cuticular surface, the assignment to genera with tuberculated representatives, i.e., Cyphodillidium Verhoeff, 1939; Echinarmadillidium Verhoeff, 1901; Paxodillidium Schmalfuss, 1985; and Platanosphaera Strouhal, 1956, can be excluded. Cristarmadillidium Arcangeli, 1935; Eleoniscus Racovitza, 1907; Trichodillidium Schmalfuss, 1989; Troglarmadillidium Verhoeff, 1900; and Typhlarmadillidium Verhoeff, 1900, are known only from a few species, and their distribution is rather limited. For instance, representatives of Trichodillidium are so far known only from Greece, including Crete and adjacent islands (Schmalfuss, 1989, 2003), whereas monotypic Eleoniscus is restricted to southeastern Spain (Racovitza, 1907; Schmalfuss, 2003). A vast majority of all species of the family Armadillidiidae belong to the genus Armadillidium (Schmidt, 2003); therefore it is the most parsimonious course of action to interpret the Hungarian specimen as a representative of this genus. In addition, the autochtonous European distribution of Armadillidium (Schmalfuss, 2000, 2013) strengthens the argument in favour of attributing the Hungarian specimen to that genus.

\section{Armadillidium sp.}

Figures 3.1-6, 4.1-3, 5.1

Material. The specimen studied (MM 2015.513.1; collections of the Matra Museum of Hungarian Natural History Museum at Gyöngyös, Hungary) comes from the molluscan clay of the Wind Brickyard section at Eger (Figures 1-2). It is preserved three-dimensionally in poorly lithified sand; no 


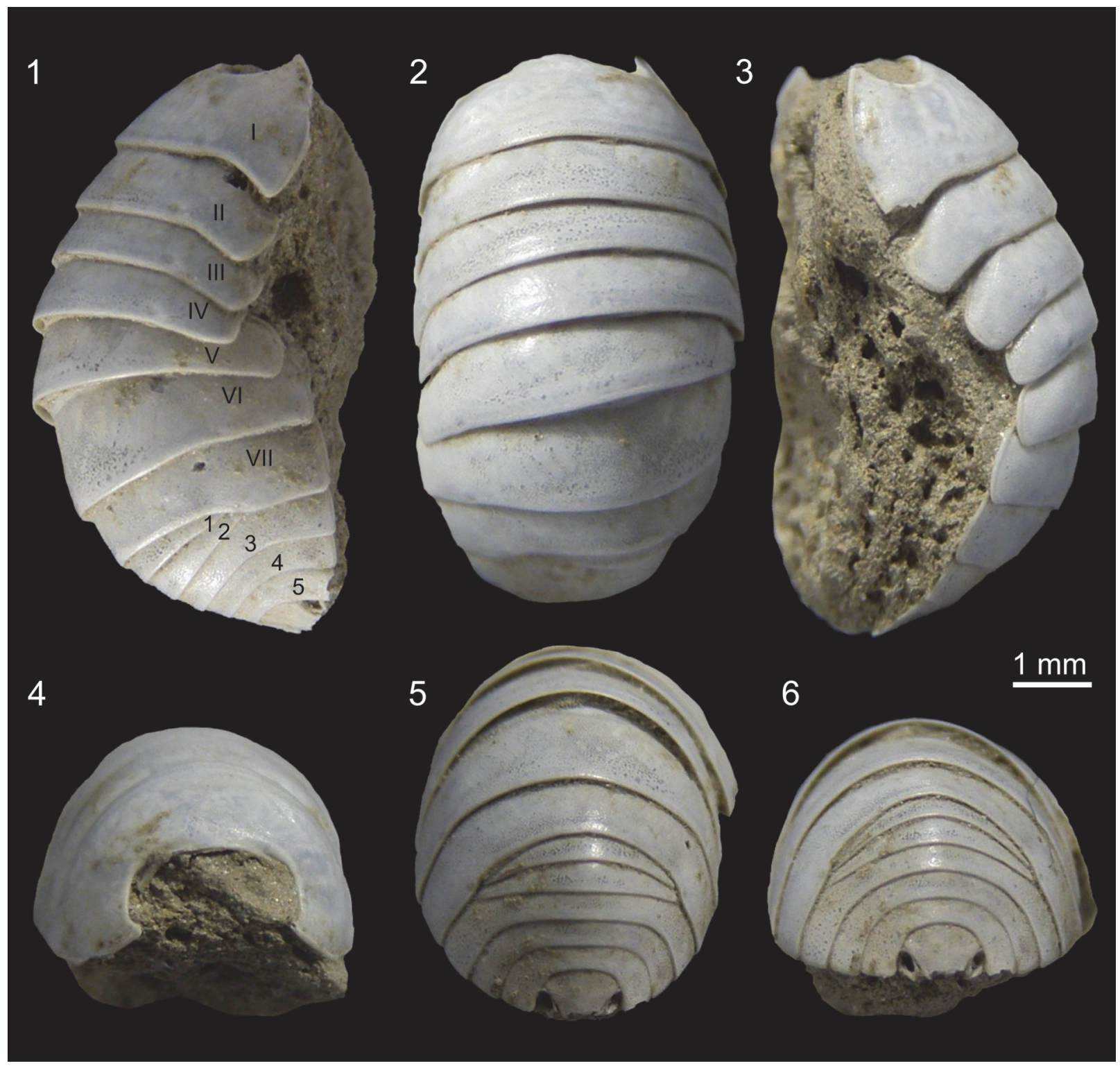

FIGURE 3. Armadillidium sp. from the upper Oligocene of Eger, Hungary (MM 2015.513.1). 1. Lateral (right) view. 2. Dorsal view. 3. Lateral (left) view. 4. Anterior view; note the missing cephalon. 5. Postero-dorsal view. 6. Posterior view. Roman numerals indicate pereonites; Arabic numerals refer to pleonites.

deformation is observed (Figures 3.1-6, 5.1). All cuticular surfaces are preserved.

Description. Body oblong-ovate, approximately twice as long as wide, lateral outlines subparallel, dorsal surface strongly vaulted and smooth. Cephalon not preserved, but presumed to have been wider than long (based on the slit in pereonite I). Pereonites distinctly wider than long, subequal, each being approximately $1.5 \mathrm{~mm}$ in length. No epimera separated on any pereonite. Epimera of pereonite I with acute posterior corner, without schisma. Pleon as wide as pereon. Pleonites 1 and 2 covered at sides by pereonite VII. Terminal seg- ment of pleon (pleotelson) trapezoidal or triangular in shape, apparently tapering posteriorly, with broken posterior margin and probably not extending beyond epimera of pleonite 5 . Uropods broken.

Remarks. The specimen is very well preserved; however, it lacks head and appendages, which are crucial for the taxonomy of oniscidean isopods as discussed by Schmidt (2002). Based on the comparisons discussed above it is assigned to the Armadillidiidae and identified tentatively as a representative of Armadillidium. The studied specimen shows overall similarity to Armadillidium vulgare (e.g., Sars, 1899, p. 189, pl. 81; Richardson, 1905, 

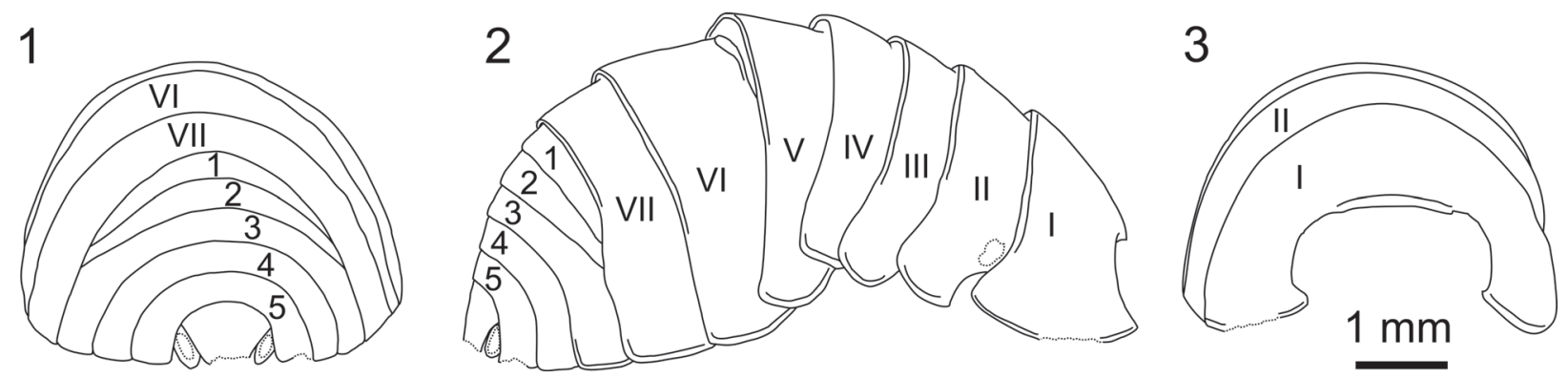

FIGURE 4. Armadillidium sp. from the upper Oligocene of Eger, Hungary (MM 2015.513.1), interpretative line drawings. 1. Posterior view. 2. Lateral (right) view. 3. Anterior view. Roman numerals indicate pereonites; Arabic numerals refer to pleonites.

p. 666, figure 706; Van Name, 1936, p. 276, figures 157-158; Frankenberger, 1959, plate 2, figure 11; Hegna, 2010, figures 2A-B) and related species such as $A$. pulchellum (Zenker, 1798) (e.g., Sars, 1899, p. 191, plate 83, figure 4). Close comparison, however, is not possible. Despite the fact that the chance of discovery of additional specimens is minimal, we refrain from erecting a new species based on the present material because of lack of sufficient number of distinguishing characters.

\section{DISCUSSION}

\section{Terrestrial Isopods as Fossils}

Because the cuticle of terrestrial isopods contains only minor amounts of materials resistant to chemical and physical degradation (Neues et al., 2007), the probability of burial and fossilization in terrestrial environments is low. In most cases, extinct oniscideans are preserved as amber inclusions (Spahr, 1993; Schmalfuss, 2003; Dunlop, 2010; Broly et al., 2013, 2015). In view of this, reports of such animals from other settings are worth noting. In fact, there are only a few reports on fossil oniscideans that are not contained in amber. Based on a single specimen of an oniscidean isopod from the Pleistocene clastic sediments of France, Dollfus (1904) described a new genus and species, Eoarmadillidium granulatum. Dallens and Bouthier (1985) reported $A$. vulgare from the Pleistocene of France. Heer (1865) described a new species, $A$. molassicum, from the middle Miocene clastic sediments of Germany. Schmidt (2008), however, disputed the attribution of the Heer's specimen to isopods; a millipede would be a more fitting identification. Contrary to these instances when only a single specimen was recovered, Eubelum rusingaense Morris, 1979 was described from numerous specimens from the lower Miocene lacustrine sediments of Rusinga
Island, Lake Victoria, Kenya. As far as the preservation is concerned, the Hungarian specimen seems to surpass most of the occurrences discussed above. Its cuticle is preserved virtually intact, which is usually not the case in arthropod fossils, which are tens of millions years old. In fact, Armadillidium sp. from Eger is the oldest armadillidiid isopod reported from siliciclastic sediments (Table 1). It documents that the cuticular surfaces of oniscoidean isopods may be very well preserved under specific conditions in siliciclastic settings; better preservation is documented only from amber inclusions.

\section{From the Land to the Sea}

The specimen of Armadillidium sp. from the Wind Brickyard at Eger is preserved in a marine setting. Similar to many crinochetan isopods, Armadillidium possesses fairly complex "lungs" in the pleopod exopodites (e.g., Frankenberger, 1959; Wägele, 1989; Hornung, 2011) and is, therefore, adapted to subaerial habitats. The aquatic life habit of a number of Crinocheta evolved secondarily (Tabacaru, 1999; Schmidt, 2008), but this is not the case for Armadillidium, which is a fully terrestrial animal. Thus, the marine setting of the present isopod fossil occurrence was not its natural habitat. The fossil apparently does not represent a moult, which typically consists of two parts and is shed biphasically (Schöbl, 1880; Tait, 1917; Vernet and Charmantier-Daures, 1994; CharmantierDaures and Vernet, 2004; Hornung, 2011). Moreover, freshly moulted individuals of terrestrial isopods often consume their exuvia to regain mineral content (Steel, 1993; Hornung, 2011, figure 3C). In short, the Eger fossil is interpreted as a corpse. Post-mortem transport could have damaged delicate joints between segments of the exoskeleton, especially over longer distances, which would be required for a terrestrial isopod to land into a 


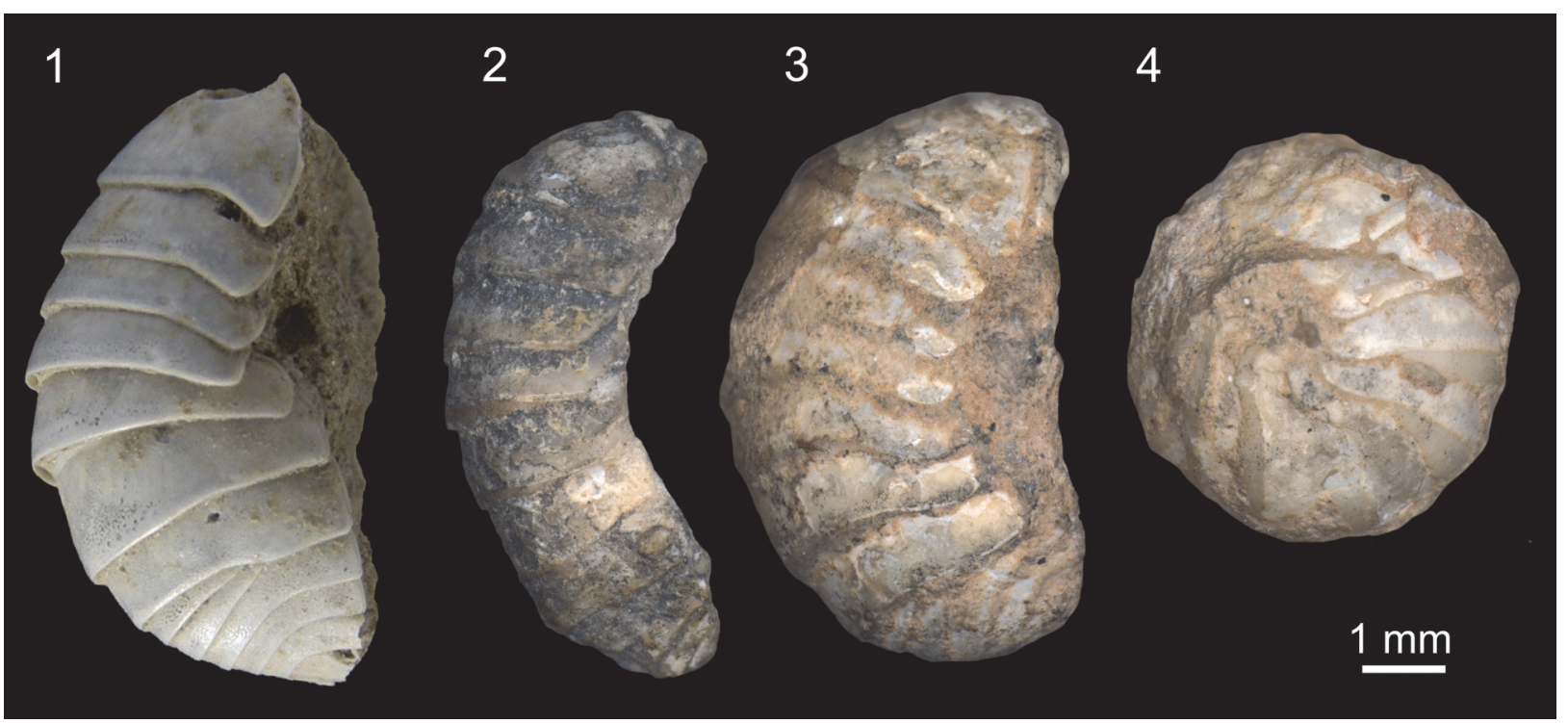

FIGURE 5. Fossil oniscidean isopods preserved in natural posture. 1. Armadillidium sp., upper Oligocene of Hungary (MM 2015.513.1). 2-4. Eubelum rusingaense Morris, 1979, lower Miocene of Kenya, deposited in the collections of the Natural History Museum, London. 2. BMNH In. 61035. 3. BMNH In. 61036. 4. BMNH In. 61037 (fully enrolled specimen).

marine depositional setting. It is reasonable to assume that the animal was introduced into marine waters when alive and then died almost instantly as a result of high salinity. Rapid burial must have occurred to ensure preservation of the delicate exoskeleton.

The body of the described specimen is slightly bent and recalls the preservation state of Eubelum rusingaense. Morris (1979, p. 74, figures 1-11; see also Figures 5.2-4 here) described and figured several specimens of this terrestrial isopod from lacustrine deposits in "many degress of enrollment, from a flat to a relaxed arched condition; six specimens show a nearly complete enrollment with only a slight gape between the frontal line and the pleotelson." Apparently, the animals displayed defensive behaviour, i.e., enrollment, when entering the water, although without much effect. The Hungarian specimen described herein may illustrate a similar phenomenon, although it is far from being completely rolled up. It, however, has a curved shape and shows an ability to conglobation when alive.

Yet, how does a fully terrestrial arthropod become introduced undamaged into a marine setting? Oniscidean isopods usually live under stones and logs and are often found inside rotting tree trunks. The molluscan clay at Wind Brickyard contains fossilised driftwood fragments (Dávid, 2004), which apparently were taken far away from the coast prior to final settlement and burial. Most probably the isopod crept out of a crevice and was washed into the sea, since it was not buried within the driftwood as would be expected if the log had sunk with the occupant inside. In fact, soil-dwelling arthropods are often associated with driftwood (e.g., Coulson et al., 2002, and references therein) and rafting has even been suggested to be a dispersal agent (Donlan and Nelson, 2003). Nevertheless, terrestrial invertebrates occupying crevices in the wood could easily be washed out into the sea. Marine conditions, however, were lethal for them (but see Coulson et al., 2002). The specimen of Armadillidium recorded herein is considered to be one of such "unhappy travellers." Alternatively, the animal could have been caught by waves while crawling on the seashore. Since representatives of the Armadillidiidae occur in a wide range of habitats and some Armadillidium species live close to the seashore, e.g., A. album or A. fallax (Holthuis, 1945; Vandel, 1962; Warburg, 1993), such scenario would be equally possible.

\section{Distribution of Armadillidium}

As far as European distribution is concerned, armadillidiids are autochtonous to the Mediterranean area (Schmaffuss, 2000, 2013; Schmidt, 2003), which they have occupied at least since the Paleogene, as documented by the present report and previously published occurrences (for a review see Broly et al., 2013; Table 1). Armadillidium has a radiation centre in the northeastern Mediterra- 
nean area (Schmalfuss, 2000, 2013). The dating of the origin of the group is unknown at present, but the late Oligocene material from Germany (Spahr, 1993) and the roughly coeval Hungarian specimen reported herein suggest that it is at least 26 million years old. The genus Armadillidium, however, may well be paraphyletic (Schmalfuss, 2013); therefore, any conclusions made at the present state of knowledge are premature. Today, Armadillidium exhibits cosmopolitan distribution due to introducing some species (e.g., A. vulgare) to other areas (e.g., the New World) by humans (Van Name, 1936; Garthwaite et al., 1995; Jass and Klausmeier, 2000).

\section{CONCLUSION}

Despite the extreme scarcity of fossil terrestrial isopods in marine siliciclastic sediments, a uniquely preserved specimen of Oniscidea is reported from the upper Oligocene strata of the Wind Brickyard in Eger (Hungary). Although it does not preserve a cephalon or appendages, it is attributed to unidentified species of Armadillidium, a widespread genus which today occurs in a most of Europe. Its occurrence in the late Oligocene of Hungary together with roughly coeval record from Germany suggests that the genus is at least 26 million years old. The specimen from Wind Brickyard is remarkable in the near-perfect preservation of its cuticular surfaces, suggesting that rather soft and fragile cuticle of terrestrial isopods may be very well preserved under specific conditions in siliciclastic marine settings. Better preservation is documented only from amber inclusions. The specimen is interpreted as a drowned individual that found itself either trapped on a piece of driftwood or caught by waves while on the seashore. It is likely that rotting logs, now preserved as fossils at the Wind Brickyard contained some passengers, isopods in particular, before they were washed out to sea.

\section{ACKNOWLEDGEMENTS}

Access to comparative material at the Natural History Museum, London, was provided by C.J.T. Mellish. R. Summerfield (NHM, London) is thanked for assistance in photography of Eubelum rusingaense. J.W.M. Jagt kindly helped with improving the English of the earlier draft. Three anonymous reviewers are thanked for their constructive criticism. This research has been supported by the Slovak Research and Development Agency under contract no. APVV-0436-12, European Commis- sion's Research Infrastructure Action via SYNTHESYS Project (GB-TAF 4495) and by Hungarian Scientific Research Fund (OTKA K112708).

\section{REFERENCES}

Arcangeli, A. 1935. Isopodi terrestri di caverne della Spagna (Collezione del Museo di Storia Naturale di Madrid). Eos, Revista Española de Entomologia, 10:171-195.

Bachmayer, F. 1947. Zwei neue Asseln aus dem Torton von Deutsch-Altenburg, Hundsheimer Berg (Niederösterreich). Sitzungsberichte der Österreichischen Akademie der Wissenschaften, mathematisch-naturwissenschaftliche Klasse, Abteilung I, 156:363-369.

Bachmayer, F. 1949. Zwei neue Asseln aus dem Oberjurakalk von Ernstbrunn, Niederösterreich. Sitzungsberichte der Österreichischen Akademie der Wissenschaften, mathematisch-naturwissenschaftliche Klasse, Abteilung I, 158:263-270.

Bachmayer, F. 1955. Die fossilen Asseln aus den Oberjuraschichten von Ernstbrunn in Niederösterreich und von Stramberg in Mähren. Sitzungsberichte der Österreichischen Akademie der Wissenschaften, mathematisch-naturwissenschaftliche Klasse, Abteilung I, 164:255-273

Báldi, T. 1973. Mollusc fauna of the Hungarian Upper Oligocene (Egerian). Studies in stratigraphy, palaeoecology, palaeogeography and systematics. Akadémiai Kiadó, Budapest.

Báldi, T. 1983. Magyarországi oligocén és alsómiocén formációk. Akadémiai Kiadó, Budapest.

Báldi, T. 1998. Magyarország epikontinentális oligocén képződményeinek rétegtana, p. 419-435. In Bérczi, I. and Jámbor, Á. (eds.), Magyarország geológiai képződményeinek rétegtana. MOL Rt and MÁFI, Budapest.

Báldi, T. and Seneš, J. 1975. OM Egerian. Die Egerer, Pozdraner, Puchkirchner Schichtengruppe und die Bretkaer Formation. Chronostratigraphie und Neostratotypen 5. Veda, Bratislava.

Brandt, J.F. 1833. Conspectus monographiae crustaceorum oniscidorum latreillii. Byulleten' Moskovskogo Obshchestva Ispytatelej Prirody, 6:171-193.

Broly, P., Deville, P., and Maillet, S. 2013. The origin of terrestrial isopods (Crustacea: Isopoda: Oniscoidea). Evolutionary Ecology, 27:461-476.

Broly, P., Maillet, S., and Ross, A.J. 2015. The first terrestrial isopod (Crustacea: Isopoda: Oniscoidea) from Cretaceous Burmese amber of Myanmar. Cretaceous Research, 55:220-228.

Brusca, R.C., Coelho, V.R., and Taiti, S. 2007. Isopoda, p. 503-542. In Carlton, J.T. (ed.), The ight and Smith Manual: intertidal invertebrates from central California to Oregon, $4^{\text {th }}$ edition. University of California Press, Berkeley.

Budde-Lund, G. 1885. Crustacea Isopoda Terrestria per familia et genera et species descripta. Nielsen \& Lydiche, Hauniae [= Copenhagen]. 
Charmantier-Daures, M. and Vernet, G. 2004. Moulting, autotomy, and regeneration, p. 161-255. In Forest, J., von Vaupel Klein, J.C., and Schram, F.R. (eds.), Treatise on zoology - anatomy, taxonomy, biology. The Crustacea, revised and updated from the Traité de Zoologie 1. Brill, Leiden.

Coulson, S.J., Hodkinson, I.D., Webb, N.R., and Harrison, J.A. 2002. Survival of terrestrial soil-dwelling arthropods on and in seawater: implications for transoceanic dispersal. Functional Ecology, 16:353-356.

Dalens, H. and Bouthier, A. 1985. Oniscoides subfossiles trouvés dans une fosse gallo-romaine du lle siècle après J. C. Bulletin de la Société d'Histoire naturelle de Toulouse, 121:85-88.

Dávid, Á. 1993. Trace fossils on molluscs from the Molluscan Clay/Late Oligocene, Egerian/ - a comparison between two localities (Wind Brickyard, Eger, and Nyárjas Hill, Novaj, NE Hungary). Scripta Geologica, Special Issue 2:75-82.

Dávid, Á. 1999. Predation by Naticid Gastropods on Late - Oligocene (Egerian) Molluscs Collected from Wind Brickyard, Eger, Hungary. Malakológiai Tájekoztató, 17:11-19.

Dávid, Á. 2004. The occurrence of the ichnogenus Teredolites in Egerian Age Formations from Hungary, p. 12. In Mikuláš, R. (ed.), $4^{\text {th }}$ International Bioerosion Workshop, Prague, August 30-September 3, 2004, Abstract Book. Institute of Geology, Academy of Sciences, Prague.

Dollfus, A. 1904. Sur un nouveau genre et une nouvelle espèce de crustacé isopode fossile découvert à Bouzigues (Herault). Feuille des Jeunes Naturalistes, (4)34:145-146.

Donlan, C.J. and Nelson, P.A. 2003. Observations of invertebrate colonized flotsam in the eastern tropical Pacific, with a discussion of rafting. Bulletin of Marine Science, 72:231-240.

Dunlop, J.A. 2010. Bitterfeld amber, p. 57-68. In Penney, D. (ed.), Biodiversity of fossils in amber from the major world deposits. Siri Scientific Press, Manchester.

Dunlop, J.A., Scholtz, G., and Selden, P.A. 2013. Waterto-land transitions, p. 417-439. In Minelli, A., Boxshall, G., and Fusco, G. (eds.), Arthropod Biology and Evolution. Springer, Berlin/Heidelberg.

Etter, W. 2014. A well-preserved isopod from the Middle Jurassic of southern Germany and implications for the isopod fossil record. Palaeontology, 57:931-949.

Feldmann, R.M. 2009. A new cirolanid isopod (Crustacea) from the Cretaceous of Lebanon: dermoliths document the pre-molt condition. Journal of Crustacean Biology, 29:373-378.

Fodor, R. 2001. Bioeróziós nyomok fels\&\#337;-oligocén korallokon (Wind-féle téglagyár, Eger)/Bioerosion on Late Oligocene Corals (Wind Brickyard, Eger). Földtani Közlöny, 130:179-196.

Frankenberger, Z. 1959. Fauna ČSR 14: Stejnonožci suchozemští - Oniscoidea. Nakladatelství Československé Akademie Věd, Praha.
Garthwaite, R.L., Lawson, R., and Sassaman, C. 1995. Population genetics of Armadillidium vulgare in Europe and North America. Crustacean Issues, 9:145-199.

Guinot, D., Wilson, G.D.F., and Schram, F.R. 2005. Jurassic isopod (Malacostraca: Peracarida) from Ranville, Normandy, France. Journal of Paleontology, 79:954-960.

Heer, O. 1865. Die Urwelt der Schweiz. F. Schulthess, Zürich.

Hegna, T.A. 2010. Photography of soft-bodied crustaceans via drying, whitening, and splicing. Journal of Crustacean Biology, 30:351-356.

Holthuis, L. 1945. Notes on the Dutch Armadillidiidae with the description of Armadillidium album Dollfus. Zoologische Mededeelingen, 25:65-71.

Hornung, E. 2011. Evolutionary adaptation of oniscidean isopods to terrestrial life: Structure, physiology and behaviour. Terrestrial Arthropod Reviews, 4:95-130.

Hyžný, M., Bruce, N., and Schlögl, J. 2013. An appraisal of the fossil record for the Cirolanidae (Malacostraca: Peracarida: Isopoda: Cymothoida), with a description of a new cirolanid isopod crustacean from the early Miocene of the Vienna Basin (Western Carpathians). Palaeontology, 56:615-630.

Jass, J. and Klausmeier, B. 2000. Endemics and immigrants: North American terrestrial isopods (Isopoda, Oniscidea) north of Mexico. Crustaceana, 73:771799.

Kensley, B. and Schotte, M. 1989. Guide to the Marine Isopod Crustaceans of the Caribbean. Smithsonian Institution Press, Washington, D.C./London.

Kussakin, O.G. 1979. Marine and brackish-water Isopoda of cold and temperate (boreal) waters of the Northern Hemisphere. Part 1. Flabellifera, Valvifera, and Tyloidea. National Academy of Sciences, U.S.S.R., Zoology, 122:1-470. (In Russian)

Kvaček, Z. and Hably, L. 1991. Notes on the Egerian stratotype flora at Eger (Wind brickyard), Hungary, Upper Oligocene. Annales Historico-Naturales Musei Nationalis Hungarici, 83:49-82.

Latreille, P.A. 1802-1803. Histoire naturelle, générale et particulière, des Crustacés et des Insectes; vol. 3. F. Dufart, Paris.

Latreille, P.A. 1804. Histoire naturelle, générale et particulière, des crustacés et des insectes. Cloportides; vol. 7. F. Dufart, Paris.

Latreille, P.A. 1817. Les crustacés, les arachnides et les insectes. In G. Cuvier (ed.), Le règne animal distribué d'après son organisation, pour servir de base à l'histoire naturelle des animaux et d'introduction à l'anatomie comparée. Déterville, Paris, 653 pp.

Legrand, J.J. 1946. Les coaptations sexuelles des Oniscoidea. Bulletin Biologique de la France et de la Belgique, 80:241-388.

Morris, S.F. 1979. A new fossil terrestrial isopod with implications for the East African Miocene land form. Bulletin of the British Museum (Natural History), Geology, 32:71-75. 
Nagler, C., Haug, C., Resch, U., Kriwet, J., and Haug, J.T. 2016. 150 million years old isopods on fishes: a possible case of palaeo-parasitism. Bulletin of Geosciences, 91:1-12.

Neues, F., Ziegler, A., and Epple, M. 2007. The composition of the mineralized cuticle in marine and terrestrial isopods: A comparative study. CrystEngComm, 9:1245-1251.

Novák, O. 1872. Über eine neue Isopoden-Gattung aus dem tertiären Süsswasser-Kalk von Waltsch. Sitzungsberichte der Königlich Böhmischen Gesellschaft der Wissenschaften, Mathematisch-naturwissenschaftliche Klasse, 1872:39-45.

Perkovsky, E.E., Zosimovich, V.Y., and Vlaskin, A.P. 2010. Rovno amber, p. 116-136. In Penney, D. (ed.), Biodiversity of fossils in amber from the major world deposits. Siri Scientific Press, Manchester.

Piller, W.E., Harzhauser, M., and Mandic, O. 2007. Miocene Central Paratethys stratigraphy - current status and future directions. Stratigraphy, 4:71-88.

Poore, G.C.B. and Bruce, N.L. 2012. Global Diversity of Marine Isopods (Except Asellota and Crustaceans Symbionts). PLoS ONE, 7(8): e43529.

Racovitza, E. 1907. Biospéologica. IV. Isopodes terrestres (première série). Archives de Zoologie expérimentale et générale, 4eSérie, 7:145-225, pls. 10-20.

Racovitza, E-G. and R. Sevastos. 1910. Proidotea haugi, n. g. et n. sp., isopode Oligocène de Roumanie, et les Mesidoteini, nouvelle sousfamille des Idotheidae. Archives de Zoologie expérimentale et générale, 6:175-200.

Richardson, H. 1905. Monograph on the isopods of North America. Bulletin of the United States National Museum, 54:i-xi,1-727.

Sars, G.O. 1899. An account of the Crustacea of Norway. II, Isopoda. Bergen Museum, Bergen.

Schmalfuss, H. 1985. Zwei bemerkenswerte neue Landisopoden-Arten von der griechischen Insel Paxi. Stuttgarter Beiträge zur Naturkunde, Serie A 380:11 pp.

Schmalfuss, H. 1989. Die Land-Isopoden (Oniscidea) Griechenlands. 10. Beitrag: Gattung Trichodillidium g. n. (Armadillidiidae). Sitzungsberichte der österreichischen Akademie der Wissenschaften, mathematisch-naturwissenschaftliche Klasse, Abteilung I, 197:207-214.

Schmalfuss, H. 2000. Distributional patterns in the Greek species of the terrestrial isopod genus Armadillidium Brandt, 1833. The Belgian Journal of Zoology, 130 (Supplement 1):75-80.

Schmalfuss, H. 2003. World catalog of terrestrial isopods (Isopoda: Oniscidea). Stuttgarter Beiträge zur Naturkunde, Serie A, 654:1-341.

Schmalfuss, H. 2013. The species of the genus Armadilliidum (Isopoda: Oniscidea) known from Greece. Stuttgarter Beiträge zur Naturkunde, Serie A, Neue Serie 6:13-20.

Schmidt, C. 2002. Contribution to the phylogenetic system of the Crinocheta (Crustacea, Isopoda). Part 1
(Olibrinidae to Scyphaidae s. str.). Mitteilungen aus dem Museum für Naturkunde in Berlin (Zoologische Reihe), 78:275-352.

Schmidt, C. 2003. Contribution to the phylogenetic system of the Crinocheta (Crustacea, Isopoda). Part 2 (Oniscoidea to Armadillidiidae). Mitteilungen aus dem Museum für Naturkunde in Berlin (Zoologische Reihe), 79:3-179.

Schmidt, C. 2008. Phylogeny of the terrestrial Isopoda (Oniscidea): a review. Arthropod Systematics \& Phylogeny, 66:191-226.

Schöbl, J. 1880. Über die Fortpflazung isopoder Crustaceen. Archiv für Mikroskopische Anatomie, 17:125140.

Serrano, M.L., Vega, F.J., and Coutiño, M.A. 2007. Terrestrial isopods included in Miocene amber from Chiapas, Mexico. Geological Society of America, Abstracts with Programs, 39(6):76-77.

Sfenthourakis, S. and Taiti, S. 2015. Patterns of taxonomic diversity among terrestrial isopods. ZooKeys, 515:13-25.

Spahr, U. 1993. Ergänzungen und Berichtigungen zu R. Keilbachs Bibliographie und Liste der Bernsteinfossilien. Verschiedene Tiergruppen, ausgenommen Insecta und Araneae. Stuttgarter Beiträge zur Naturkunde, Serie B, 194:1-77.

Srivastava, G.P., Shukla, M., Kumar, P., Kumar, M., and Prakash, A. 2006. Record of pillbug (Armadillidium) and millipede (Polyxenus) remains from the resin lumps of Warkali Formation (Upper Tertiary), Kerala Coast. Journal of the Geological Society of India, 67:715-719.

Steel, C.G.H. 1993. Storage and translocation of integumentary calcium during the moult cycle of the terrestrial isopod Oniscus asellus (L.). Canadian Journal of Zoology, 71:4-10.

Strouhal, H. 1956. Zoologische Studien in West-Griechenland. VI. Teil. Isopoda terrestrial, II.: Armadillidiidae. Sitzingsberichte der österreichischen Akademie der Wissenschaften, mathematisch-naturwissenschaftliche Klasse, Abteilung I, 165:585-618.

Tabacaru, I. 1999. L'adaptation à la vie aquatique d'un remarquable trichoniscide cavernicole, Cantabroniscus primitivus Vandel, et le problème de la monophylie des isopodes terrestres. Travaux de l'Institut de Spéléologie "Emile Racovitza», 37-38:11-131.

Tait, J. 1917. Experiments and observations on Crustacea. Part II. Moulting of isopods. Proceedings of the Royal Society of Edinburgh, 37:59-68.

Taiti, S, Ferrara, F., and Schmalfuss, H. 1991. Evolution and biogeography of the family Eubelidae (Crustacea, Oniscidea), p. 23-30. In Juchalt, P. and Mocguard, J.P. (eds.), Biology of Terrestrial Isopods III (Third International Symposium on the Biology of Terrestrial Isopoda 1990). Université de Poitiers, Poitiers.

Tauber, A. F. 1950. Sphaeroma bachmayeri nov. sp., eine Schwimmassel aus dem Torton des Wiener Beckens. Sitzungsberichte der Österreichischen 
Akademie der Wissenschaften, mathematisch-naturwissenschaftliche Klasse, Abteilung I, 159:101-108.

Van Name, W.G. 1936. The American Land and FreshWater Isopod Crustacea. Bulletin of the American Museum of Natural History, 71:1-535.

Vandel, A. 1961. Les isopodes terrestres de l'île de Minorque. Archives de Zoologie expérimentale et générale, 4e Série 99: 249-265.

Vandel, A. 1962. Isopodes terrestres (deuxième partie), pp. 417-931. In Faune de France, 66. P. Lechevalier, Paris.

Vega, F J., Bruce, N.L., Serrano, L., Bishop, G.A., and Perrilliat, M. del C. 2005. A review of the Lower Cretaceous (Tlayúa Formation: Albian) Crustacea from Tepexi de Rodríguez, Puebla, Central Mexico. Bulletin of the Mizunami Fossil Museum, 32:25-30.

Verhoeff, K.W. 1900. Über paläarktische Isopoden (2. Aufsatz). Zoologischer Anzeiger, 23:117-130.

Verhoeff, K.W. 1901. Über paläarktische Isopoden (3. Aufsatz). Zoologischer Anzeiger, 24:33-41.

Verhoeff, K.W. 1918. Ueber augenlose Armadillidien und kritische Prüfung der Familie Armadillidiidae. Archiv für Naturgeschichte, 8A:160-170.

Verhoeff, K.W. 1919. Zur Kenntnis der Gattungen Porcellium und Armadillidium in Deutschland. Archiv für Naturgeschichte, 83A:1-37.

Verhoeff, K.W. 1939. Über einige balkanische Isopoda terrestria (69. Isopoden-Aufsatz). Studien aus dem Gebiete der allgemeinen Karstforschung, der wissenschaftlichen Höhlenkunde, der Eiszeitforschung und den Nachbargebieten, B. Biologische Serie, 6:5-10.
Vernet, G. and Charmantier-Daures, M. 1994. Mue, autotomie et régénération, p. 153-194. In Grassé, P.-P. (ed.), Traite de Zoologie. Anatomie, systématique, biologie. Tome 7: Crustacés. Fascicule 1: Morphologie, physiologie, réproduction, systématique. Masson, Paris.

von Ammon, L. 1882. Ein Beitrag zur Kenntniss der fossilen Asseln. Sitzungsberichte der mathematischphysikalischen Classe der königlich Bayerischen Akademie der Wissenschaften, 4:507-550.

Wägele, J.-W. 1989. Evolution und phylogenetisches System der Isopoda. Stand der Forschung und neue Erkentnisse. Zoologica, 140:1-262.

Warburg, M.R. 1993. Distribution Patterns of Isopod Species in Different Habitats, p. 70-84. In Warburg, M.R. (ed.), Evolutionary Biology of Land Isopods. Springer, Berlin Heidelberg.

Weitschat, W. and Wichard, W. 2010. Baltic amber, p. 80-115. In Penney, D. (ed.), Biodiversity of fossils in amber from the major world deposits. Siri Scientific Press, Manchester.

Wilson, G.D.F., Paterson, J.R., and Kear, B.P. 2011. Fossil isopods associated with a fish skeleton from the Lower Cretaceous of Queensland, Australia - direct evidence of a scavenging lifestyle in Mesozoic Cymothoida. Palaeontology, 54:1053-1068.

Zenker, C. 1798. [Descriptions of Oniscus pulchellus and Oniscus cinereus], p. 21-22. In Panzer, G. (ed.), Faunae insectorum Germanicae initia, oder Deutschlands Insecten 62. Felsecker, Nürnberg. 